\title{
Effects of Lax Vox Voice Therapy on Respiration and Phonation in Patients with Parkinson's Disease
}

\author{
Hye-Rim Chae ${ }^{\mathrm{a}}$, Seong Hee Choi ${ }^{\mathrm{a}, \mathrm{b}}$, Chul-Hee Choi ${ }^{\mathrm{a}, \mathrm{b}}$, Kyoungjae Lee ${ }^{\mathrm{a}, \mathrm{b}}$ \\ ${ }^{a}$ Graduate Program in Audiology \& Speech-Language Pathology, Daegu Catholic University, Gyeongsan, Korea \\ ${ }^{b}$ Department of Audiology \& Speech-Language Pathology, Daegu Catholic University, Gyeongsan, Korea
}

\author{
Correspondence: Seong Hee Choi, PhD \\ Department of Audiology \& Speech-Language \\ Pathology, Daegu Catholic University, 13-13 \\ Hayang-ro, Gyeongsan 38430, Korea \\ Tel: $+82-53-850-2542$ \\ Fax: +82-53-359-6780 \\ E-mail: shgrace67@gmail.com \\ Received: July 5, 2019 \\ Revised: August 14, 2019 \\ Accepted: August 14, 2019 \\ This work is based on a partial data from the first \\ author's master thesis.
}

\begin{abstract}
Objectives: Parkinson's disease (PD) is a degenerative disease of the central nervous system that mainly affects sensory and motor function. PD patients have difficulty in controlling their vocal pitch and loudness, and poor self-monitoring due to their sensory disorder. Among semi-occluded vocal tract exercises, Lax Vox is a holistic method that provides biofeedback by focusing on the interaction of breathing, resonance, and phonation by tube phonation in water. The purpose of this study was to investigate the effect of Lax Vox voice therapy on respiration and phonation in patients with PD. Methods: Ten patients with PD (4 males and 6 females) underwent Lax Vox voice therapy six times a week for 6 weeks. To assess the effectiveness of Lax Vox voice therapy, aerodynamic, acoustic evaluation, GRBAS scale, electroglottography, and Korean Voice Handicap Index (KVHI)-10 were performed before and after voice therapy. Results: Significant improvement in aerodynamic, acoustic, auditory-perceptual rating measures, and KVHI-10 score was yielded following Lax Vox voice therapy. After treatment, significantly increased vital capacity (VC) and maximum phonation time (MPT); and reduced subglottal pressure (Psub) were observed. Cepstral peak prominence (CPP) was significantly increased and smoothed pitch perturbation quotient (sPPQ), vF0, shimmer, amplitude perturbation quotient (APQ), smoothed APQ (sAPQ), peak-amplitude variation $(\mathrm{vAm})$ were significantly decreased after treatment. Moreover, Voice Range Profile (VRP) was extended and KVHI-10 scored significantly lower. Conclusion: Current outcomes confirmed that significantly positive effects were found in respiration and phonation change following Lax Vox voice therapy for patients with PD. Therefore, Lax Vox voice therapy, in addition to Lee Silverman Voice Treatment, can be useful for an effective treatment option in patients with PD.
\end{abstract}

Keywords: Parkinson's disease, Motor and sensory disorder, Lax Vox voice therapy, Semioccluded vocal tract exercises (SOVTE)
파킨슨병(Parkinson's disease, PD)은 도파민을 생성하는 흑질 세포의 변성으로 인하여 광범위한 운동 및 비운동 기능이상으로 발생한다(Jankovic, 2008; Kim, Ghang, \& Bae, 2002). 초기 증상은 강직(rigidity), 완서(bradykinesia), 떨림(tremor), 자세 이상(postural instability)과 같은 운동장애가 있으며, 비운동장애 증상으로 는 우울증, 정서적-동기(motivation)결함과 같은 신경정신적장애, 고인지 기능의 저하로 인한 내적 단서의 상실, 자기인식 저하, 내부 모니터링 감소와같은 감각장애, 특히, 감소된 운동을 인지하지 못하 는 감각의 변화와 자율신경계 이상과 같은 증상을 포함한다 $(\mathrm{Gelb}$,
Oliver, \& Gilman, 1999; Poewe, 2008).

운동기능 이상 중 가장 두드러진 증상은 강직(rigidity)으로 발성 시 호흡 및 후두 근육에서도 나타난다(Solomon \& Charron, 1998). 강직된 호흡 근육으로 인하여 발화의 길이가 짧아지고 말산출 중 간에 발화를 쉬는 구간이 증가하며, 이로 인해 발화의 길이가 짧아 지고 긴장음(strain)과 기식음(breathiness)을 보이기도 한다. 또한, 횡격막이 수축할 때 흥벽의 근육강직성으로 인하여 흥곽의 움직임 이 감소되어 정상적인 화자보다 구강압(oral pressure)이 낮아지고, 이로 인하여 발화 시 강도(intensity)와 말명료도(intelligibility)가 
Hye-Rim Chae, et al. • Effects of Lax Vox Voice Therapy in Patients with Parkinson's Disease

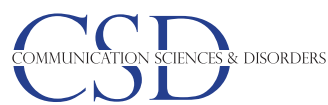

감소하게 된다. 한편, 강직된 후두 근육은 성대를 내전(adduction) 하지 못하게 하고, 이러한 불완전한 성대내전은 결국 음성 강도의 감소, 단조로운 음도(monotone), 거친 소리(hoarseness), 음성 진전 (vocal tremor) 및 기식음 등과 같은 과소기능적 발성장애의 특성 을 초래한다(Darley, Aronson, \& Brown, 1969; Gath \& Yair, 1998; Perez, Ramig, Smith, \& Dromey, 1996). 또한, 후두의 불안정성과 발음에 관여하는 근육의 협응운동 저하로 최대발성지속시간(maximum phonation time)이 감소하며, 갑상피열근(thyroarytenoid muscle)과 윤상갑상근(cricothyroid muscle)의 강직으로 인해 기본 주파수(fundamental frequency)의 범위가 감소하여 정상인에 비 해 말소리가 단조롭다(Aronson, 1990; Baker, Ramig, Luschei, \& Smith, 1998; Lee, 2007; Ramig, 1994, 1995).

파킨슨병은 운동체계의 결함이 지배적이지만, 감각장애로도 매 우 잘 알려져 있다(Hillen \& Sage, 1996; Koller, 1984; Snider, Fahn, Isgreen, \& Cote, 1976). 파킨슨병 환자의 음성 이상은 근육의 강직 과 더불어 감각-운동 통합장애 때문에 자신의 음성을 정확하게 모 니터링하지 못하여 음량이나 음도를 조절하지 못하고 이로 인하여 감소된 음성 강도와 제한된 음도 범위를 보인다(Brown \& Marsden, 1988; Fox, Morrison, Ramig, \& Sapir, 2002).

현재까지 파킨슨병 환자의 증거기반의 표준적인 음성치료방법 으로 리실버만 음성치료(Lee Silverman Voice Treatment, LSVT) 가 가장 널리 사용되고 있다(Ramig, 1994). LSVT는 파킨슨병 환자 에게 음성 강도를 증가시켜 호흡을 개선하고, 성대내전을 도모하여 음질을 향상시키며, 말명료도를 개선하는 방법으로 그 효과성이 널리 증명되어 왔다(Choi, 2011). 또한, 도파민 약물치료나 뇌심부 자극술(deep brain stimulation, DBS)도 파킨슨병 환자의 음성기 능 개선에 도움을 준다고 보고된 연구도 있었으나(Choi, 2012), 이 와는 반대로, 운동기능의 호전만큼 음성기능은 개선되지 않고, LSVT와 같은 음성치료를 동반할 때 더 효과적이라고 보고된 연구 도 있었다(Spielman et al., 2011). 이외에 음성 증폭기, 지연청각피드 백(delayed auditory feedback), 착용할 수 있는(wearable) 강도조절 생체피드백(bio-feedback) 장치 및 차폐 장치 등이 파킨슨병 환자 의 음성치료에 사용되었는데, 그중 생체피드백 장치가 파킨슨병 환 자의 음성 강도를 모니터링하는 데 매우 유용한 것으로 나타났다 (Rubow \& Swift, 1985). 또한, 이러한 장치들은 음성의 명료도와 삶 의 질을 향상시키는 것으로 보고되었으나, 모든 상황에서 불편한 장치를 착용해야 하는 불편함이 있다(Schulz \& Grant, 2000).

한편, Lax Vox 음성치료는 호흡, 발성 및 후두의 상호작용에 영 향을 미치는 총체적인 기법으로, 반폐쇄성도훈련(semi-occluded vocal tract exercises, SOVTE) 중 하나이다. SOVTE는 성도(vocal tract)의 앞부분이나 뒷부분을 수축하여 구강에서 음향 압력을 증 가시켜 더 많은 공명 감각피드백을 줄 수 있으며, 성대 진동은 증가 시키면서 접촉 시의 충격을 감소시켜 성대진동으로 인한 성대의 손 상을 최소화할 수 있다. 주로 직업적 음성사용자의 워밍업(warming-up)이나 과기능적 음성장애 환자에게 긴장을 이완시켜주는 데 효과적이라고 보고되었다(Arias \& Cudeiro, 2008; Berry et al., 2001; Choi, 2017; Fadel et al., 2016; Kim, Lee, Choi, \& Choi, 2017; Lim, Choi, Kim, \& Choi, 2016; Titze, 2006).

Lax Vox 음성치료는 실리콘 튜브를 물에 넣어 발성하는 기법인 데 짧은 시간에 발성 메커니즘의 기능을 즉시 수정하여 발성을 용 이하게 해 주며 발성 중 물거품은 생체피드백을 제공해 준다. 튜브 발성 시 물에 의해 증가된 구강압은 공명강을 넓혀 불필요한 긴장 을 예방하고 튜브는 소리에 영향을 미치는 성도를 연장하는 역할 을 한다. 또한, 성도가 반폐쇄되면서 구강압이 증가하게 되고 이로 인해 입 뒤쪽의 압력(back pressure)이 증가하면서 성문변압(transglottal pressure) 및 발성역치압력(phonation threshold pressure)에 영향을 주게 된다. 그 결과 성대임피던스가 증가하고 성문변압과 발 성역치압력이 감소하게 되어 적은 노력으로 음성을 생성할 수 있게 됨으로써 더욱 효율적이고 경제지향적인 음성을 산출할 수 있다. 또한, 튜브 발성 동안 후두가 수직적으로 하강하게 함으로써 외후 두근의 긴장을 감소시켜 부드러운 성대 접촉을 하기 위한 최적화 된 상태를 만들어 준다(Choi, 2017; Guzman, Rubin, Muñoz, \& Jackson-Menaldi, 2013; Kim et al., 2017; Laukkanen, Titze, Hoffman, \& Finnegan, 2008; Sihvo \& Denizoglu, 2013; Titze, 2002a, 2002b, 2006).

Lax Vox 음성치료는 튜브의 직경과 물의 깊이를 조절하여 과소 및 과다기능적 발성장애 모두에게 사용이 가능하다. 과다기능적 발성장애 환자에게는 물의 깊이를 얕게 하여 낮은 유량 저항(flow resistance)으로 후두 근육의 이완과 음성효율을 향상시키는 것을 목표로 하는 반면, 과소기능적 발성장애 환자에게는 높은 유량 저 항을 위해 깊이를 깊게 조절하여 후두 근육의 이완 및 효율적인 음 성산출, 후두 근육의 활성화를 목표로 할 수 있다(Simberg \& Laine, 2007; Sovijärvi, 1969).

현재까지 Lax Vox 음성치료는 과소 및 과다기능 음성장애를 가 진 환자들 대상으로 음성 개선의 효과성이 보고되었으며(Chae, Kim, Lee, \& Choi, 2019; Kim \& Choi, 2018; Lim et al., 2016), 아직까 지 과소기능적 발성장애인 파킨슨병 환자에게 적용하여 그 효과 를 보고한 연구는 없었다. 따라서 본 연구는 Lax Vox 음성치료 동 안 발성과 함께 발생하는 물거품이 내부 모니터링에 어려움을 보이 는 감각장애의 문제를 가지는 파킨슨병 환자에게 시각적으로 유용 
한 생체피드백으로 제공할 것으로 여겨지며 Lax Vox 음성치료 동 안 증가된 갑상피열근 및 윤상갑상근 움직임이 파킨슨병 환자의 강 직된 호흡 및 후두 근육을 유연하게 만들고 운동을 촉진시켜 음성 개선에 효과적일 것이라 사료된다. 따라서 본 연구는 $\operatorname{Lax} \operatorname{Vox}$ 음성 치료 전후 파킨슨병 환자의 객관적 및 주관적 음성평가 결과를 비 교함으로써 Lax Vox 음성 치료가 파킨슨병 환자의 호흡 및 발성력 에 어떠한 영향을 미치는지 살펴보고자 한다.

\section{연구방법}

\section{연구대상}

본 연구는 신경과 전문의로부터 특발성 파킨슨병(idiopathic Parkinson's disease)으로 진단받은 남자 4명, 여자 6명의 총 10 명 (평균연령 62.20土 7.86세)을 대상으로 하였다. Ramig, Countryman, Thompson과 Horii (1995)의 연구에 따르면 정상적인 인지수 준의 환자가 치료에 가장 잘 반응하므로 한국판 간이정신상태판별 검사(Korean version of Mini Mental State Examination)를 실시하 여 25점 이상의 대상자들만 대상으로 선정하였다. 대상자들은 모 두 이전에 언어치료를 받은 경험이 없었고, 신경과에서 항파킨슨 약물을 처방받아 정기적으로 복용 중이었다. 1 명은 $\mathrm{DBS}$ 를 받았으 나, 현재 거의 말을 알아듣지 못할 정도로 말명료도가 저하되었으 며, 발성강도가 매우 낮아 약물 복용 중에 있는 환자였다. 대상자들 의 인구학적 정보는 Table 1과 같다.

\section{연구절차}

대상자들은 모두 항파킨슨 약물을 복용 중이므로 사전평가를 비롯하여 음성치료 모든 회기와 사후평가에서 약물복용 3 시간 이 내에 실시하였다. 치료는 3 명당 1 그룹으로 그룹치료로 실시하였으

Table 1. Participants' information

\begin{tabular}{ccccccc}
\hline $\begin{array}{c}\text { Participant } \\
\text { no. }\end{array}$ & $\begin{array}{c}\text { Age } \\
\text { (yr) }\end{array}$ & Gender & $\begin{array}{c}\text { H\&Y } \\
\text { stage }\end{array}$ & $\begin{array}{c}\text { Duration of } \\
\text { disease (yr) }\end{array}$ & $\begin{array}{c}\text { Medica- } \\
\text { tions }\end{array}$ & DBS \\
\hline 1 & 53 & F & 2 & 10 & Yes & No \\
2 & 67 & F & 2 & 7 & Yes & No \\
3 & 57 & M & 3 & 16 & Yes & Yes \\
4 & 53 & F & 1 & 2 & Yes & No \\
5 & 72 & F & 2 & 10 & Yes & No \\
6 & 56 & F & 2 & 10 & Yes & No \\
7 & 59 & M & 2 & 12 & Yes & No \\
8 & 61 & F & 2 & 5 & Yes & No \\
9 & 73 & M & 3 & 15 & Yes & No \\
10 & 71 & M & 2 & 2 & Yes & No \\
\hline
\end{tabular}

H\&Y stage $=$ Hoehn and Yahr stage; DBS= deep brain stimulation .
며, 회기당 40 분, 주 1 회 간격으로 6주간 총 6회 실시하였다. 본 연구 에서는 Tyrmi, Radolf, Horáček와 Laukkanen (2017)의 연구방법 에 따라 길이 $35 \mathrm{~cm}$, 내경 $10 \mathrm{~mm}$, 외경 $13 \mathrm{~mm}$ 의 실리콘 튜브와 $500 \mathrm{~mL}$ 물병을 사용하였으며, Lax Vox 음성치료의 단계는 Table 2 와같다.

1 단계는 자세 및 호흡훈련과 발성 없이 거품내기, 2단계는 발성 과 함께 거품내기, 3 단계는 최적음 찾기, 4-5단계는 최적음 향상시 키기, 6단계는 일반화 단계로 구성하였다. Lax Vox 음성치료 프로 토콜을 바탕으로 파킨슨병 환자들의 음성특성을 고려하여 최적음 향상시키기 단계를 늘려 6회로 선정하였다. 물의 깊이는 회기마다 1-2 cm로 시작하여 $10 \mathrm{~cm}$ 까지 조절하였다. 물의 깊이가 깊을수록 성문접촉률이 증가한다고 하였으나, 파킨슨병 환자들의 강직성으 로 인해 처음부터 깊은 깊이는 거품내기에 어려움이 있어 $1-2 \mathrm{~cm}$ 깊 이로 시작하여 점차 늘려 나갔다.

1 회기에서는 자세 및 호흡훈련과 발성 없이 거품내기를 실시하 였다. 얼굴, 목, 등, 가슴을 쭉 펴서 올바른 자세를 유지한 다음 코로 충분히 숨을 들이마신 후 입으로 내뱉는 복식호흡을 실시하여 근 육을 이완시켰다. 자세 및 호흡훈련이 끝난 후 물병을 몸 가까이 놔 두고 올바른 자세를 유지하여 물병에 $1-2 \mathrm{~cm}$ 깊이로 실리콘 튜브를 넣었다. 입술로 튜브를 감싸 '우’ 모양을 만들어 코로 숨을 들이마신 뒤, 입으로 내쉬면서 물거품을 15 초간 내도록 하였다.

2 회기에서는 ‘우' 또는 ‘후’를 발성하며 15 초간 거품내기를 실시하 였다. 이때, 물의 깊이에 따른 성대의 진동과 신체 변화를 느껴본 후 느낌을 이야기하도록 하였다.

3 회기에서는 발성과 함께 거품내기를 실시하여 최적음을 찾도록 하였다. '우' 또는 '후'를 발성할 때 물거품의 세기가 발성의 시작과 끝까지 일정하게 유지되는 수준의 음성을 최적음으로 하였으며, 최 적음을 찾은 후에는 최적음을 길거나짧게 발성하도록 하였다.

4-5회기에서는 최적음을 향상시키는 단계로서 최적음을 사용하 여 물거품을 내며 저음과 고음을 각각 발성하도록 하였으며, 활창,

Table 2. Lax Vox voice therapy protocol

\begin{tabular}{ll}
\hline Level & \multicolumn{1}{c}{ Description } \\
\hline I & $\begin{array}{l}\text { Relaxing and focusing on posture and breathing } \\
\text { Bubbling without phonation }\end{array}$ \\
III & $\begin{array}{l}\text { Bubbling with phonation } \\
\text { IV }\end{array} \quad \begin{array}{l}\text { Advance using the new phonation style (1): sustained phonation } \\
\text { (middle-low-high pitch), staccato }\end{array}$ \\
V & $\begin{array}{l}\text { Advance using the new phonation style (2): gliding pitches up and down, } \\
\text { melody }\end{array}$ \\
VI & Generalization
\end{tabular}


스타카토, 멜로디 훈련을 실시하였다. 활창은 낮은 음에서 높은 음 으로, 높은 음에서 낮은 음으로 활창하였으며, 멜로디 훈련에서는 '생일축하', '산토끼', '학교종이 땡땡땡', '오빠 생각', '고향의 봄' '사 랑으로', ‘만남’ 등 짧은 노래에서 긴 노래로 가창하기 훈련을 실시 하였다.

6회기에서는 일반화를 위해 발성을 동반하여 거품을 내는 중에 실리콘 튜브 혹은 물병을 서서히 빼고 발성은 그대로 유지하도록 하였다. 실리콘 튜브 없이 '후' 발성을 하며 음도 및 강도를 변화시켰 으며, 음절-단어-문장(예: 인사하기)-책 읽기-대화로 일반화 훈련을 실시하였다.

\section{공기역학적 평가}

공기역학적 평가를 하기 위해 PAS (Phonatory Aerodynamic System; Model 6600, Kay-PENTAX, Montvale, NJ, USA)를 이용 하여 음성치료 전후 폐활량(vital capacity), 성문하압(subglottal pressure), 최대발성지속시간을 측정하였다. 폐활량은 편안하게 앉 은 자세에서 코로 숨을 깊게 들이마신 다음 입으로 최대한 내뱉도 록 유도하여 측정하였다. 마찬가지로 편안하게 앉은 자세에서 마스 크를 쓰고 숨을 깊게 들이마신 다음 편안한 목소리로 모음/가를 최대한 길게 발성하도록 유도하여 총 3 회 중 가장 긴 시간을 최대발 성지속시간으로 선택하였다. 성문하압은 마스크를 쓴 상태에서 빨 대를 입 안에 $3 \mathrm{~cm}$ 넣어 혀 위에 위치시킨 다음 평상시와 같은 크기 의 목소리로 /파파파파파/를 3회 실시하여 측정치의 평균값을 계산 하여 측정하였다.

\section{음향학적 평가}

치료효과를 측정하기 위하여 소음이 통제된 검사실에서 치료 전후 환자의 음성을 수집하였다. 대상자의 입과 마이크 사이 거리 는 $10 \mathrm{~cm}$ 유지한 다음, 평상시와 같은 목소리 크기로 유성음으로만 구성된 문장인 ‘5월 5일은 어린이날이에요'(Choi, 2018)를 CSL (Computerized Speech Lab; Model 4500, Kay-Pentax)의 Real Time Pitch (RTP)에서 녹음한 후 발화시 평균 강도를 측정하였다. 이후 CSL의 Analysis of Dysphonia Speech and Voice (ADSV)를 이용 하여 녹음된 문장의 켑스트럼을 분석하여 CPP (cepstral peak prominence)를 측정하고 스펙트럼 분석을 통하여 L/H ratio (low/ high spectral ratio)를 측정하였다.

CSL의 Multi-Dimensional Voice Program (MDVP)을 이용하 여 편안한 음도와 강도로 모음/가를 5 초간 3 회 연장 발성하여 녹 음하였다. 5 초 중 안정구간 1 초를 설정한 다음 기본주파수 관련 파 라미터 $\mathrm{F} 0$, jitter, $\mathrm{PPQ}, \mathrm{sPP}, \mathrm{vF}_{0}$ 와 강도 변이 관련 파라미터 shim- mer, $\mathrm{APQ}, \mathrm{sAPQ}, \mathrm{vAm}$, 진전 관련 파라미터 FTRI, ATRI, 잡음 관 련 파라미터 NHR, VTI, SPI, 음성 일탈 관련 파라미터 DVB, DSH, $\mathrm{DUV}$ 를 분석한 후 3 회의 평균값을 측정하였다.

발성 범위는 CSL의 Voice Range Profile (VRP)을 사용하였다. 편안한 음도로 모음///를 발성한 다음 가장 낮은 음도와 가장 높 은 음도를 발성하고 가장 낮은 음도에서 가장 높은 음도로, 가장 높 은 음도에서 가장 낮은 음도로 활창하여 최대 및 최소 음도와 음도 범위를 측정하였다. 최대 및 최소 강도와 강도범위는 음도범위를 측정하는 방법과 같이 편안한 강도에서 발성한 다음, 가장 높은 강 도와 가장 낮은 강도에서 발성을 유도하여 측정하였다.

\section{청지각적 평가}

GRBAS는 5년 이상 음성장애 임상경험이 있는 1 급 언어재활사 2 명이 치료 전후 대상자들의 모음/1/ 연장 발성을 듣고 평가하였다. 총 4 점 척도로 0 점은 정상, 1 점은 경도, 2 점은 중도, 3 점은 고도를 의 미한다. 이에 따른 평가자 간 신뢰도는 치료 전 $92 \%$, 치료 후 $90 \%$ 로 나타났다. 평가자 간 점수가 일치하지 않는 경우에는 평가자가 동시 에 듣고 최종적으로 동의한 점수를 측정치로 정하였다.

\section{전기성문파형 검사}

편안하게 앉은 자세에서 대상자의 갑상연골을 중심으로 양측 피 부에 전극을 부착하여 고정시킨 후, 대상자에게 편안한 음도와 강 도로 모음//를 3 초간 연장 발성하도록 하였다. CSL의 Real Time EGG Analysis를 이용하여 모음//의 3 초 중 안정구간 1 초를 설정 한 후 성문폐쇄율(closed quotient, CQ)을 분석하여 측정하였다.

\section{음성장애지수}

한국어판음성장애지수(Korean Voice Handicap Index-10, KVHI10; Yun, Kim, Son, \& Choi, 2008) 설문지를 읽고 자신의 음성장애 가 어느 정도에 해당하는지 표시하도록 하였다. 각 질문은 5점 척 도로 0 점(전혀 그렇지 않다), 1 점(거의 그렇지 않다), 2 점(가끔 그렇 다), 3점(자주 그렇다), 4 점(항상 그렇다)으로 전체 질문에 대한 답 을 모두 더해서 총 점수(0-40점)를 계산하였다.

\section{통계분석}

수집된 자료는 SPSS Statistics version 22.0을 이용하여 통계처리 를 하였다. 치료 전후 호흡 및 발성 능력을 비교하기 위해 Wilcoxon signed-ranks test를 실시하였으며 95\% 수준에서 유의성을 검증하 였다. 


\section{연구결과}

\section{공기역학적 평가 결과}

$\mathrm{PAS}$ 를 이용한 음성치료 전후 공기역학적 평가 결과는 Table 3과 같다. 폐활량은 치료전 $1.80 \mathrm{~L}$ 에서 치료후 $2.20 \mathrm{~L}$ 로, 최대발성지속 시간은 치료전 14.16 초에서 치료후 18.85 초로 증가하였으며, 성문 하압은 치료전 $10.47 \mathrm{cmH}_{2} \mathrm{O}$ 에서 치료후 $7.18 \mathrm{cmH}_{2} \mathrm{O}$ 로 감소하였 으며, 폐활량, 최대발성지속시간, 성문하압 모두 치료 전후 유의한 차이를 보였다 $(p<.05)$.

\section{음향학적 평가 결과}

$\mathrm{ADSV}$ 를 이용한 음성치료 전후 켑스트럼 및 스펙트럼 분석결과 는 Table 4, Figure 1과 같다. CPP는 치료전 $6.862 \mathrm{~dB}$ 에서 치료후 $9.553 \mathrm{~dB}$ 로, $\mathrm{L} / \mathrm{H}$ ratio는 치료전 $33.188 \mathrm{~dB}$ 에서 치료후 $33.310 \mathrm{~dB}$ 로 증가하였다. $\mathrm{L} / \mathrm{H}$ ratio는 치료 전후 유의한 차이를 보이지 않았으나 ( $p>$.05), CPP는 유의한 차이를 보였다 $(p<.05)$.

$\mathrm{MDVP}$ 를 이용한 음성치료 전후 음향학적 평가 결과는 Table 5, Figure 2 와 같다. 기본주파수 관련 파라미터 중 남성의 기본주파수 는 치료전 $147.250 \mathrm{~Hz}$ 에서 치료후 $133.845 \mathrm{~Hz}$ 로 감소하였고, 여성 의 기본주파수는 치료전 $181.410 \mathrm{~Hz}$ 에서 치료후 $207.735 \mathrm{~Hz}$ 로 증 가하였으나 유의미한 차이는 없었다. jitter는 치료전 $1.204 \%$ 에서 치료후 $0.764 \%$ 로, $\mathrm{PPQ}$ 는 치료전 $0.683 \%$ 에서 치료후 $0.450 \%$ 로 감 소하였으나 통계적으로 유의미한 차이는 없었다. $\mathrm{sPPQ}$ 는 치료전 $0.856 \%$ 에서 치료후 $0.559 \%$ 로, $\mathrm{vF}_{0}$ 는 치료전 $1.449 \%$ 에서 치료후

Table 3. Comparison of aerodynamic measures before and after Lax Vox voice therapy

\begin{tabular}{lcccc}
\hline & Before $(\mathrm{N}=10)$ & After $(\mathrm{N}=10)$ & $Z$ & $p$-value \\
\hline VC & $1.80(1.26-2.02)$ & $2.20(1.74-3.04)$ & $-2.040^{*}$ & $.041^{*}$ \\
MPT & $14.16(10.93-15.53)$ & $18.85(15.35-20.61)$ & $-2.497^{*}$ & $.013^{*}$ \\
Psub & $10.47(9.15-13.10)$ & $7.18(6.72-8.26)$ & $-2.090^{*}$ & $.037^{*}$
\end{tabular}

Values are presented as median (25\%tile-75\%tile).

$\mathrm{VC}=$ vital capacity; $\mathrm{MPT}=$ maximum phonation time; $\mathrm{Psub}=$ subglottal pressure . ${ }^{*} p<.05$.

Table 4. Comparison of cepstral measures before and after Lax Vox voice therapy

\begin{tabular}{lcccc}
\hline & Before $(\mathrm{N}=10)$ & After $(\mathrm{N}=10)$ & $Z$ & $p$-value \\
\hline CPP & $6.862(6.511-9.602)$ & $9.553(9.064-9.746)$ & $-2.090^{*}$ & $.037^{*}$ \\
L/H ratio & $33.188(32.139-35.439)$ & $33.310(30.993-36.789)$ & -0.153 & .878
\end{tabular}

Values are presented as median (25\%tile-75\%tile).

$\mathrm{CPP}=$ cepstral peak prominence; $\mathrm{L} / \mathrm{H}$ ratio $=$ low/high spectral ratio. ${ }^{*} p<.05$.
$0.791 \%$ 로 유의미하게 감소하였다 $(p<.05)$.

한편, 강도변이 관련 파라미터 shimmer는 치료전 $4.111 \%$ 에서 치 료후 $2.571 \%$ 로, $\mathrm{APQ}$ 는 치료전 $2.968 \%$ 에서 치료후 $1.989 \%$ 로, $\mathrm{sAPQ}$ 는 치료전 $5.283 \%$ 에서 치료후 $2.846 \%$ 로, vAm은 치료전 $8.972 \%$ 에 서 치료후 $6.265 \%$ 로 모두 통계적으로 유의미하게 감소하였다. 잡음 관련 파라미터 중 NHR은 치료전 0.130 에서 치료후 0.126 으로, VTI (고주파 잡음대 소음비)는 치료전 0.046 에서 치료후 0.043 으로 감 소하였고 SPI는 치료전 12.523에서 치료후 16.193 으로 증가하였으 나 모두 유의미한 차이는 없었다. 진전 관련 파라미터 FTRI (기본 주파수 진전)는 치료전 $0.288 \%$ 에서 치료후 $0.194 \%$ 로 감소하였고 ATRI (강도진전)는 치료전 $1.522 \%$ 에서 치료후 $1.539 \%$ 로 증가하였 으나 통계적으로 유의미한 차이는 없었다. 음성 일탈 관련 파라미 터 DVB, DSH, DUV는 치료 전후 모두 $0.000 \%$ 로 변화가 없었다.

$\mathrm{VRP}$ 를 이용한 음성치료 전후 음향학적 평가 결과는 Table 6, Figure 3 과 같다. 최저주파수는 치료전 $130.810 \mathrm{~Hz}$ 에서 치료 후 127.140 $\mathrm{Hz}$ 로, 최고주파수는 치료전 $404.995 \mathrm{~Hz}$ 에서 치료후 $659.260 \mathrm{~Hz}$ 로, 주파수 범위는 치료전 $261.740 \mathrm{~Hz}$ 에서 치료후 $547.720 \mathrm{~Hz}$ 로, 최 소 강도는 치료전 $74.50 \mathrm{~dB}$ 에서 치료후 $67.50 \mathrm{~dB}$ 로, 최대 강도는 치 료전 $102.50 \mathrm{~dB}$ 에서 치료후 $110.50 \mathrm{~dB}$ 로, 강도범위는 치료전 26.50 $\mathrm{dB}$ 에서 치료후 $44.00 \mathrm{~dB}$ 로 확장되었으며, 모두 통계적으로 유의한 차이를 보였다 $(p<.05)$.

RTP를 이용한 음성치료 전후음향학적 평가 결과는 Table 7, Figure 4 와 같다. 치료전 발화평균 음성 강도는 $64.93 \mathrm{~dB}$ 에서 치료후 $68.85 \mathrm{~dB}$ 로 유의하게 증가하였다 $(p<.01)$.

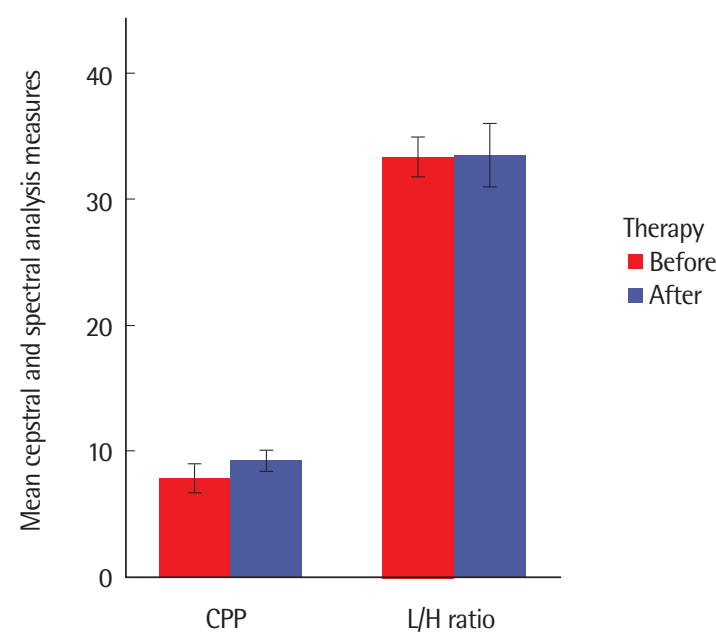

Figure 1. Comparison of cepstral measures before and after Lax Vox voice therapy.

$\mathrm{CPP}=$ cepstral peak prominence; $\mathrm{L} / \mathrm{H}$ ratio = low/high spectral ratio. 
Table 5. Comparison of MDVP measures before and after Lax Vox voice therapy

\begin{tabular}{|c|c|c|c|c|}
\hline & Before $(\mathrm{N}=10)$ & After $(\mathrm{N}=10)$ & $Z$ & $p$-value \\
\hline \multicolumn{5}{|l|}{ F0 } \\
\hline Male & 147.250 (106.190-169.965) & $133.845(118.695,176.408)$ & -0.365 & .715 \\
\hline Female & $181.410(162.470-236.543)$ & $207.735(191.735,228.168)$ & -0.943 & .345 \\
\hline Jitter & $1.204(0.558-2.148)$ & $0.764(0.532-1.163)$ & -1.274 & .203 \\
\hline PPQ & $0.683(0.357-1.242)$ & $0.450(0.313-0.701)$ & -1.376 & .169 \\
\hline sPPO & $0.856(0.511-1.532)$ & $0.559(0.476-0.739)$ & $-1.988^{*}$ & $.047^{*}$ \\
\hline $\mathrm{vF}_{0}$ & $1.449(1.059-2.260)$ & $0.791(0.640-1.023)$ & $-2.191^{*}$ & $.028^{*}$ \\
\hline Shimmer & $4.111(2.512-5.933)$ & $2.571(1.926-2.973)$ & $-2.497^{*}$ & $.013^{*}$ \\
\hline APO & $2.968(1.737-4.147)$ & $1.989(1.300-2.366)$ & $-2.497^{*}$ & $.013^{*}$ \\
\hline sAPQ & $5.283(3.354-6.643)$ & $2.846(1.875-3.466)$ & $-2.803^{* *}$ & $.005^{* *}$ \\
\hline vAm & 8.972 (5.725-15.936) & $6.265(5.381-7.530)$ & $-2.497^{*}$ & $.013^{*}$ \\
\hline NHR & $0.130(0.115-0.151)$ & $0.126(0.109-0.133)$ & -0.969 & .333 \\
\hline SPI & $12.523(7.712-21.987)$ & $16.193(5.915-21.087)$ & -0.663 & .759 \\
\hline VTI & $0.046(0.038-0.053)$ & $0.043(0.038-0.049)$ & -0.306 & .508 \\
\hline FTRI & $0.288(0.107-0.698)$ & $0.194(0.130-0.347)$ & -1.172 & .241 \\
\hline ATRI & $1.522(0.638,5.138)$ & $1.539(0.692-2.065)$ & -0.968 & .333 \\
\hline DVB & $0.000(0.000-0.000)$ & $0.000(0.000-0.000)$ & -1.000 & .317 \\
\hline DSH & $0.000(0.000-1.018)$ & $0.000(0.000-0.000)$ & -1.633 & .102 \\
\hline DUV & $0.000(0.000-2.778)$ & $0.000(0.000-0.000)$ & -1.342 & .180 \\
\hline
\end{tabular}

Values are presented as median (25\%tile-75\%tile).

$\mathrm{FO}=$ fundamental frequency; $\mathrm{PPQ}=$ pitch perturbation quotient; $\mathrm{SPPQ}=$ smoothed pitch perturbation quotient; $\mathrm{V} \mathrm{F}_{0}=$ fundamental frequency variation; $\mathrm{APQ}=\mathrm{amplitude}$ perturbation quotient; $\mathrm{SAPQ}=$ smoothed amplitude perturbation quotient; $\mathrm{VAm}=$ peak-amplitude variation; $\mathrm{NHR}=$ noise-to-harmonic ratio; $\mathrm{SPI}=$ soft phonation index; $\mathrm{VTI}=\mathrm{voice}$ turbulence index; $F T R I=$ fundamental frequency-tremor index; $A T R I=$ amplitude-tremor index; DVB= degree of voice breaks; $D S H=$ degree of sub-harmonic; DUV=degree of voiceless.

${ }^{*} p<.05,{ }^{* *} p<.01$.
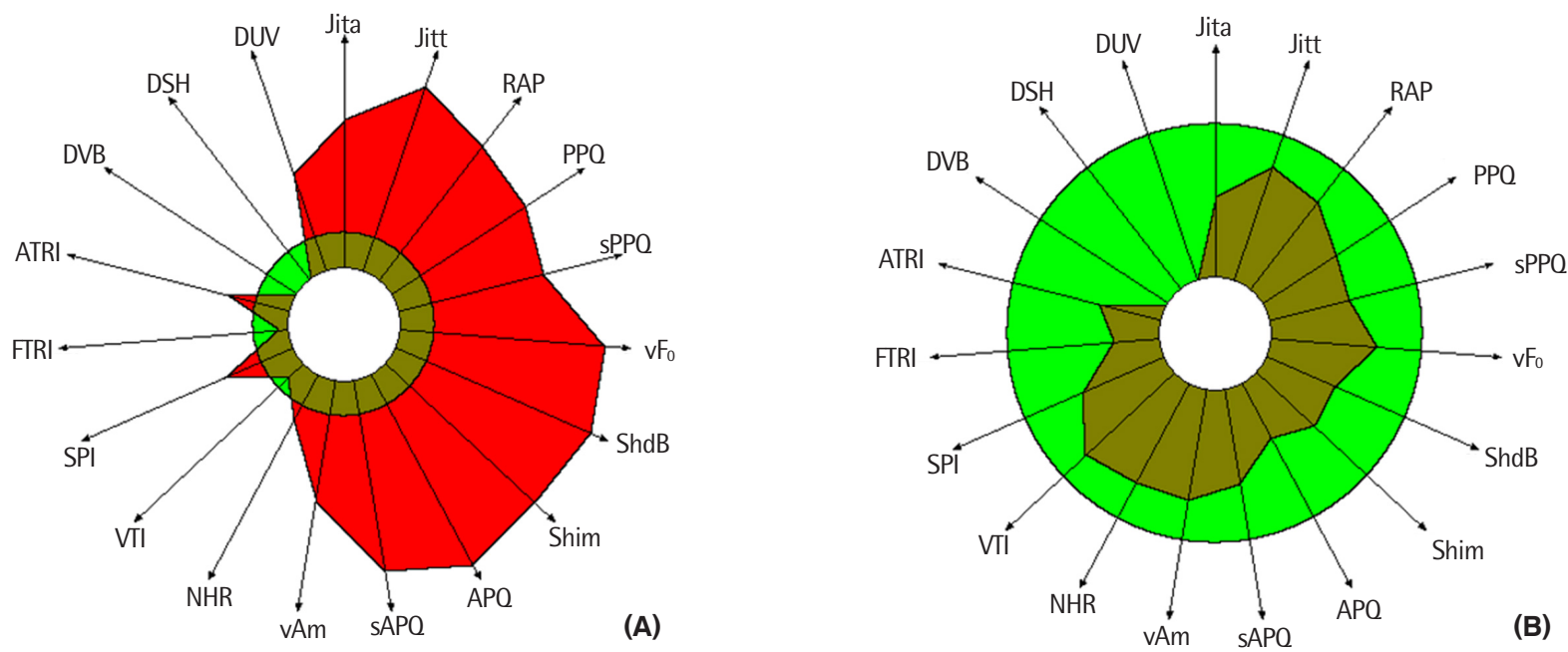

Figure 2. Comparison of MDVP measures before (A) and after (B) Lax Vox voice therapy in a male Parkinson's disease.

$\mathrm{MDVP}=$ Multi-Dimensional Voice Program; $F 0=$ fundamental frequency; $\mathrm{PPO}=$ pitch perturbation quotient; $\mathrm{SPPQ}=\mathrm{smoothed}$ pitch perturbation quotient; $\mathrm{VF} \mathrm{F}_{0}=$ fundamental frequency variation; $\mathrm{APQ}=$ amplitude perturbation quotient; $\mathrm{SAPQ}=$ smoothed amplitude perturbation quotient; $v A m=$ peak-amplitude variation; $\mathrm{NHR}=$ noiseto-harmonic ratio; $\mathrm{SPI}=$ soft phonation index; $\mathrm{VTI}=$ voice turbulence index; $\mathrm{FTRI}=$ fundamental frequency-tremor index; $\mathrm{ATRI}=$ amplitude-tremor index; DVB=degree of voice breaks; DSH= degree of sub-harmonic; DUV= degree of voiceless. 
Table 6. Comparison of VRP measure before and after Lax Vox voice therapy

\begin{tabular}{lcccc}
\hline & Before $(\mathrm{N}=10)$ & After $(\mathrm{N}=10)$ & $Z$ & $p$-value \\
\hline $\mathrm{Hz}$ & & & & \\
Min & $130.810(109.233-147.595)$ & $127.140(63.625-140.650)$ & $-2.100^{*}$ & $.036^{*}$ \\
Max & $404.995(285.653-548.075)$ & $659.260(409.475-893.083)$ & $-2.497^{*}$ & $.013^{*}$ \\
Range & $261.740(200.975-400.405)$ & $547.720(273.713-804.788)$ & $-2.599^{* *}$ & $.009^{*}$ \\
dB & & & & \\
Min & $74.50(67.00-77.00)$ & $67.50(64.75-70.00)$ & $-2.134^{*}$ & $.033^{*}$ \\
Max & $102.50(100.00-104.25)$ & $110.50(103.50-115.25)$ & $-2.073^{*}$ & $.038^{*}$ \\
Range & $26.50(24.50-35.75)$ & $44.00(35.00-49.25)$ & $-2.296^{*}$ & $.022^{*}$ \\
\hline
\end{tabular}

Values are presented as median (25\%tile-75\%tile).

${ }^{*} p<.05,{ }^{* *} p<.01$.

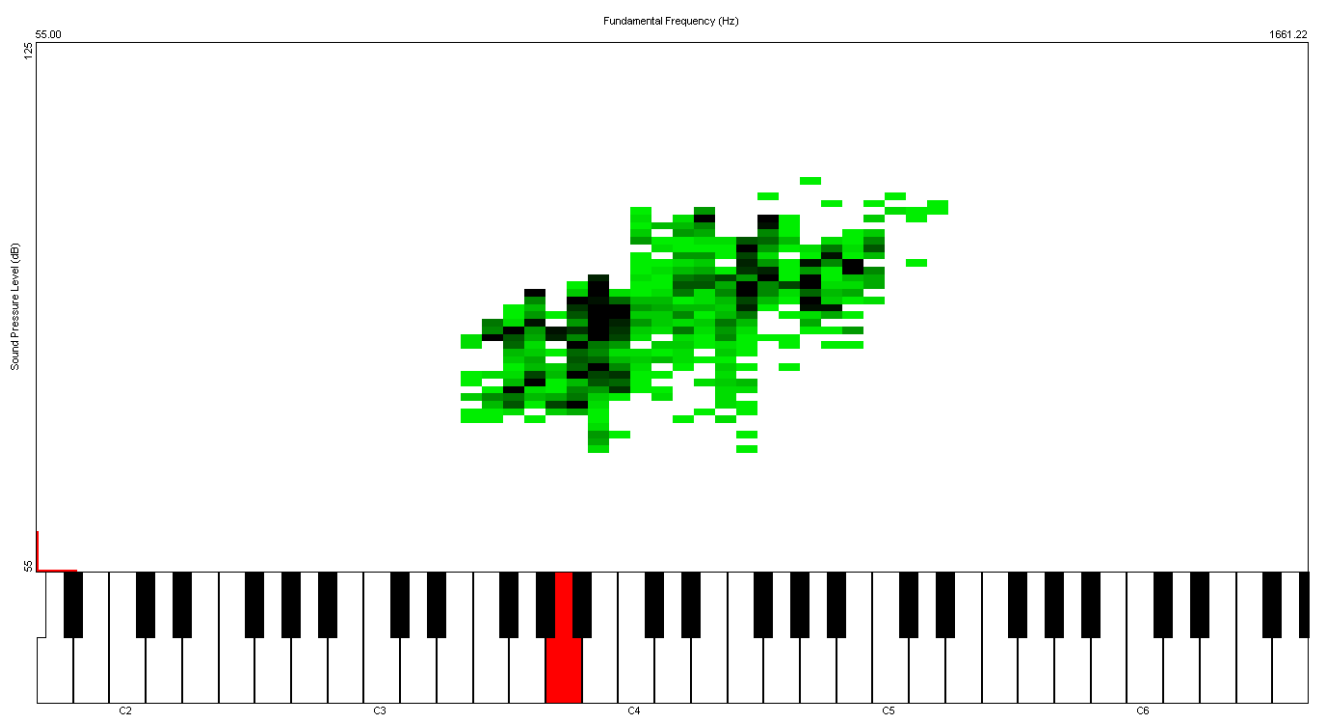

(A)

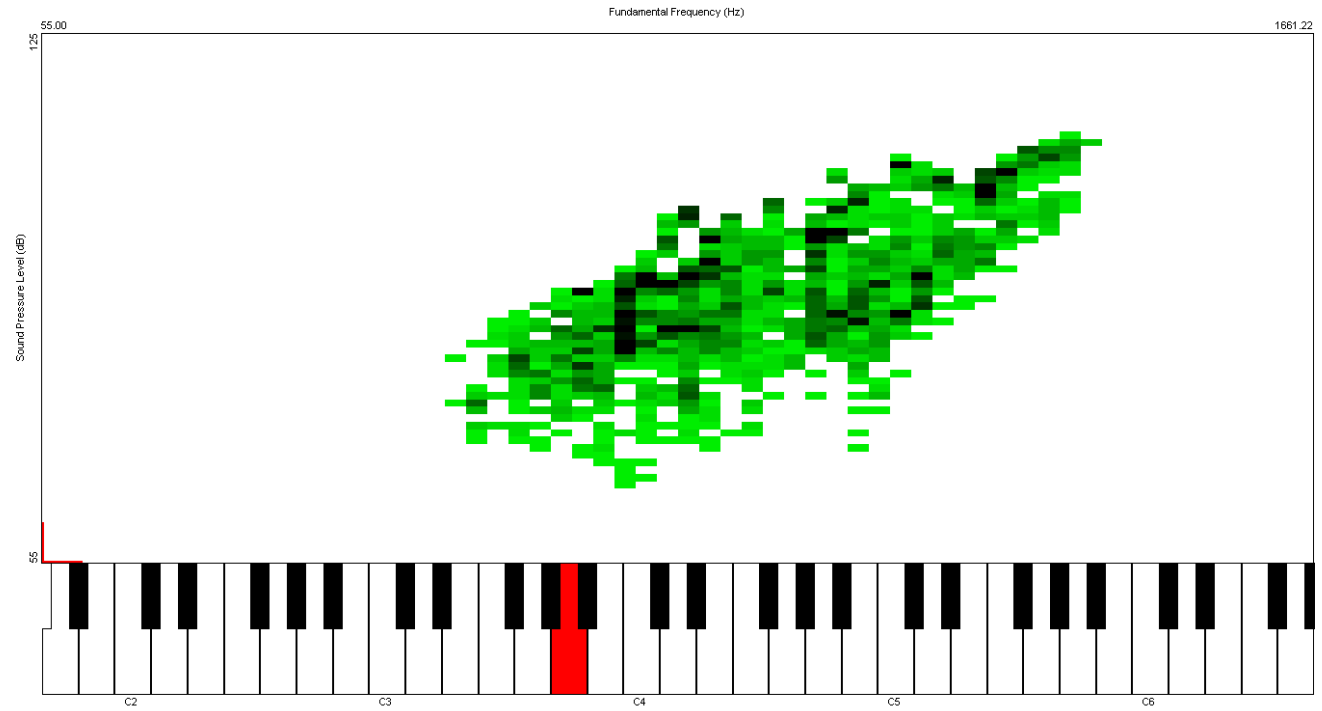

(B)

Figure 3. Comparison of Voice Range Profile measures before (A) and after (B) Lax Vox voice therapy in a female Parkinson's disease. 
Hye-Rim Chae, et al. • Effects of Lax Vox Voice Therapy in Patients with Parkinson's Disease

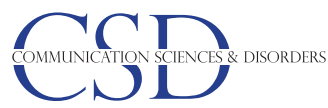

Table 7. Comparison of mean intensity measure before and after Lax Vox voice therapy

\begin{tabular}{ccccc}
\hline & Before $(\mathrm{N}=10)$ & After $(\mathrm{N}=10)$ & $Z$ & $p$-value \\
\hline Mean energy (dB) & $64.93(61.26-66.65)$ & $68.85(65.62-69.24)$ & $-2.803^{* *}$ & $.005^{* *}$
\end{tabular}

Values are presented as median (25\%tile-75\%tile). ${ }^{* *} p<.01$.

Table 8. Comparison of GRBAS measure before and after Lax Vox voice therapy

\begin{tabular}{lcccc}
\hline & Before $(\mathrm{N}=10)$ & After $(\mathrm{N}=10)$ & $Z$ & $p$-value \\
\hline $\mathrm{G}$ & $1.50(1.00-2.00)$ & $0.00(0.00-0.25)$ & -2.913 & $.004^{* *}$ \\
$\mathrm{R}$ & $1.00(1.00-2.00)$ & $0.00(0.00-1.00)$ & -2.887 & $.004^{* *}$ \\
$\mathrm{~B}$ & $1.00(0.75-2.00)$ & $0.00(0.00-0.25)$ & -2.232 & $.026^{*}$ \\
$\mathrm{~A}$ & $1.00(0.75-2.00)$ & $0.00(0.00-0.00)$ & -2.640 & $.008^{* *}$ \\
$\mathrm{~S}$ & $1.00(0.00-1.00)$ & $0.00(0.00-0.00)$ & -2.333 & $.020^{*}$ \\
\hline
\end{tabular}

Values are presented as median (25\%tile-75\%tile).

$\mathrm{G}=$ grade; $\mathrm{R}=$ roughness; $\mathrm{B}=$ breathiness; $\mathrm{A}=$ asthenia; $\mathrm{S}=$ strain.

${ }^{*} p<.05,{ }^{* *} p<.01$.

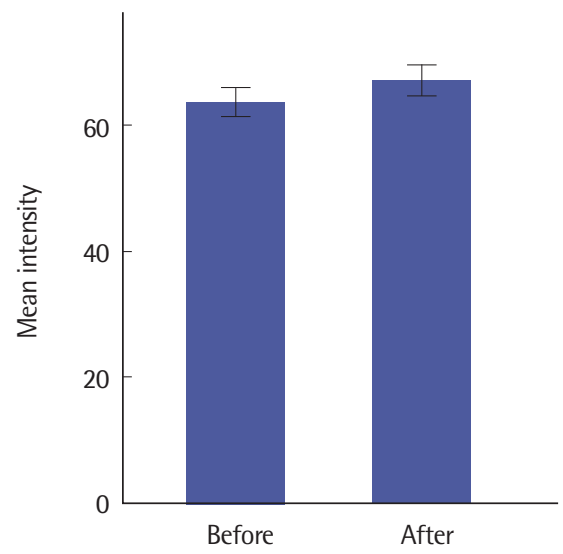

Lax Vox voice therapy

Figure 4. Comparison of mean intensity measure before and after Lax Vox voice therapy.

\section{청지각적 평가 결과}

GRBAS를 이용한 음성치료 전후 청지각적 평가 결과는 Table 8 과 같다. 전반적인 중증도는 치료전 1.50 에서 치료후 0.00 으로, 조 조성은 치료전 1.00 에서 치료후 0.00 으로, 기식성은 치료전 1.00 에 서 치료후 0.00 으로, 무력성은 치료전 1.00 에서 치료후 0.00 으로, 긴장성은 치료전 1.00 에서 치료후 0.00 으로 감소하여 통계적으로 유의한 차이를 보였다 $(p<.05)$.

\section{전기성문파형 검사 결과}

$\mathrm{EGG}$ 를 이용한 음성치료 전후 전기성문파형 검사 결과는 Table 9 와 같다. 성문폐쇄율은 치료전 $46.71 \%$ 에서 치료후 $48.86 \%$ 로 증가
Table 9. Comparison of electroglottography measure before and after Lax Vox voice therapy

\begin{tabular}{ccccc}
\hline & Before $(\mathrm{N}=10)$ & After $(\mathrm{N}=10)$ & $Z$ & $p$-value \\
\hline Closed quotient & $46.71(42.92-49.92)$ & $48.86(47.66-50.58)$ & -1.784 & .074
\end{tabular}

Values are presented as median (25\%tile-75\%tile).

Table 10. Comparison of KVHI-10 score measure before and after Lax Vox voice therapy

\begin{tabular}{ccccc}
\hline & Before $(\mathrm{N}=10)$ & After $(\mathrm{N}=10)$ & $Z$ & $p$-value \\
\hline KVHI-10 score & $12.50(4.50-28.75)$ & $7.50(4.75-4.25)$ & $-2.349^{*}$ & $.019^{*}$ \\
\hline
\end{tabular}

Values are presented as median (25\%tile-75\%tile).

$\mathrm{KVHI}=$ Korean Voice Handicap Index-10.

${ }^{*} p<.05$.

하였으나, 통계적으로 유의한차이는 보이지 않았다( $p>.05)$.

\section{음성장애지수 결과}

KVHI-10을 이용한 치료 전후 한국판 음성장애지수-10의 총점 은 Table 10 과 같다. KVHI-10의 총점이 치료전 12.50 점에서 치료 후 7.50점으로 유의하게 감소하였다 $(p<.05)$.

\section{논의 및 결론}

본 연구는 10 명의 파킨슨병 환자를 대상으로 Lax Vox 음성치료가 파킨슨병 환자의 호흡 및 발성 능력에 미치는 효과를 살펴보았다.

본 연구 결과 호흡적인 측면에서는 치료 후 폐활량이 유의미하 게 증가하였다. LSVT와 관련된 이전 연구에서는 대부분 최대발성 지속시간이 증가함으로써 호흡 능력이 개선되었다고 보고하였으 며 폐활량을 측정하여 객관적인 수치를 비교하여 보고한 연구는 없었다. 본 연구에서는 치료 전후의 폐활량을 객관적인 수치를 이 용하여 비교한 결과, Lax Vox 음성치료가 최대발성지속시간뿐만 아니라 파킨슨병 환자의 폐활량을 증가시키는 데 효과적임을 시사 하였다. 이는 Lax Vox 음성치료가 강직된 호흡 근육을 이완시켜 호 흡 능력을 향상시키는 데 도움을 주는 것으로 보인다. 대부분의 파 킨슨병 환자들이 1 회기 시에 거품을 거의 내지 못하였으나, 시각적 인 피드백 역할을 하는 물거품을 통하여 거품의 높이를 증가시켰으 며 감각장애를 보이는 파킨슨병 환자들의 폐활량을 개선시키는 데 효과적이었다. 파킨슨병 환자를 대상으로 LSVT를 실시한 선행연 구에서도 LSVT 후 최대발성지속시간이 유의미하게 증가하였다고 보고하였는데, 본 연구에서도 선행연구의 결과들과 일치된 결과를 보였다(Chu, 1998; Dromey, Ramig, \& Johnson, 1995; Jeon, 2017; Kang, 2007; Ramig et al., 1995). 
또한, 공기역학적 평가 결과, 편안한 음도와 강도로 발성하도록 하였을 때 Lax Vox 음성치료 후 성문하압이 유의하게 감소하였다. Guzman 등(2016)의 연구에서 성대마비(vocal fold paralysis) 환자 를 대상으로 Lax Vox 음성치료를 실시하였을 때 성문하압이 감소 하였다고 보고하였는데, 본 연구결과에서도 치료전 과도하게 높은 성문하압이 치료후 유의하게 낮아졌다. 이는 PAS검사 시 비슷한 강도에서 성문하압이 낮아진 것을 의미한다. Ramig과 Dromey (1996)의 연구에 의하면, LSVT 후 파킨슨병 환자들의 성문하압이 증가하였다고 보고하였으며, Dromey 등(1995)의 연구에서도 집중 음성치료 프로그램과 LSVT를 함께 실시한 후 파킨슨병 환자들의 음성 강도가 증가함에 따라 성문하압이 증가하였다고 보고하였다. 그러나 선행연구들의 대상자들은 치료전 성문하압이 3-4 $\mathrm{cmH}_{2} \mathrm{O}$ 로 본 연구의 대상자들의 치료전 평균 성문하압인 $11 \mathrm{cmH}_{2} \mathrm{O}$ 보다 낮았다. Jiang 등(1999)의 선행연구에 따르면, 동일한 음성 강도에 서 파킨슨병 환자가 일반인에 비하여 성문하압과 후두 저항(laryngeal resistance)이 더 높다고 보고하였으며, 이는 파킨슨병 환자가 발성을 하기 위해 일반인보다 더 많은 노력을 기울인다고 하였다. 또한, 파킨슨병 환자들은 주요 증상인 성대의 휨(bowing)을 보상 하기 위해 성문하압을 증가시키는데 이는 호흡 및 후두 근육의 피 로를 초래한다(Sewall, Jiang, \& Ford, 2006). 그러나, Lax Vox 음성 치료는 파킨슨병 환자들의 높아진 성문하압을 감소시킴으로써 적 은 노력으로 발성을 가능하게 함으로써 호흡 및 후두 근육의 피로 에도 영향을 미치지 않을 것으로 사료된다.

또한, 치료 후 CPP 측정치가 증가하였는데, 이는 $\mathrm{Lax} \operatorname{Vox}$ 음성치 료 후 기식성이 감소하여 음질이 개선되었음을 알 수 있다. Jeon (2017)과 Alharbi, Cannito, Buder와 Awan (2019)의 연구에서 LSVT 후 파킨슨병 환자의 $\mathrm{CPP}$ 측정치가 증가하여 음질이 개선되었다는 연구결과와 일치된 결과를 나타내어 Lax Vox 음성치료가 LSVT와 마찬가지로 음질개선에 효과가 있음을 시사하였다. 또한, 본 연구 에서는 통계적으로는 유의한 차이는 없었으나, 치료전보다 치료후 $\mathrm{L} / \mathrm{H}$ ratio 측정치가 증가하여 파킨슨병 환자들의 음성에서 잡음이 감소하였다. Lax Vox 음성치료 후 기본주파수 관련 파라미터 측정 치 $\mathrm{sAPQ}, \mathrm{vF}_{0}$ 가 감소하였는데, 이는 치료 후 기본주파수 관련 변이 가 감소하여 발성이 안정화되어 파킨슨병 환자들의 음성의 불안정 성이 감소했음을 알 수 있다. 또한 이러한 결과는 LSVT 후 기본주 파수 관련 파라미터 측정치가 감소하여 음질이 개선되었다는 선행 연구 결과와 비슷한 결과를 보여(Choi, 2011), Lax Vox 음성치료가 LSVT와 마찬가지로 파킨슨병 환자 음성의 객관적인 음향학적 지 표가 개선되었음을 나타내었다. Kent, Vorperian, Kent와 Duffy (2003)는 장기간 음도 및 강도 변이 파라미터가 신경학적 환자의 음
성을 감별하는 데 유용한 음향학적 지표라고 하였는데, 본 연구에 서도 장기간 음도 및 강도 변이 관련 파라미터인 $\mathrm{sPP}, \mathrm{vF}_{0}, \mathrm{APQ}$, $\mathrm{sAPQ}, \mathrm{vAm}$ 등이 Lax Vox 치료 후 유의미한 차이를 보여 치료 효 과를 측정하는 데 매우 유용한 음향학적 지표였다. 따라서, 이러한 장기간 음도 및 강도 변인 측정치들은 파킨슨병 환자와 같이 음성 진전처럼 불안정한 음성 신호를 가지는 신경학적 음성장애 환자의 음성을 평가하거나 치료 효과를 측정할 때에는 단기간 주파수 변 동률보다 장기간 주파수 변동률 측정치가 더욱 유용하게 사용될 수 있음을 시사하였다. 따라서, 추후에 신경학적 질환을 가진 음성 장애 환자에게는 장기간 주파수 변동률 파라미터가 주요 음향학 적 지표로서 진단 및 치료 효과를 측정하는 데 더 유용하게 사용될 수 있을 것으로 사료된다.

Lax Vox 음성치료 후 파킨슨병 환자들의 음역대가 넓어져서 주 요 음성 특징인 단조로운 음도와 단조로운 강도가 개선되었다. 이 러한 결과는 파킨슨병 환자에게 15 일간 매일 집중적으로 LSVT를 기반으로 한 언어치료를 실시한 결과 음성범위프로파일의 범위가 늘어났다는 Simberg, Rae, Kallvik, Salo와 Martikainen (2012)의 연구결과와 유사한 결과를 보였으며, 수정된 LSVT를 실시한 후 파 킨슨병 환자들의 최대 기본주파수와 기본주파수 범위가 증가하였 다는 Searl 등(2011)의 연구결과와도 비슷한 결과를 나타내었다. 이 러한 결과는 파킨슨병 환자의 윤상갑상근과 갑상피열근의 강직으 로 인하여 성대 근육의 기본주파수 범위가 제한적이었으나, Lax Vox 음성치료 후 강직된 후두 근육의 움직임이 활성화되어 성대가 유연해지고 성대운동이 촉진되어 음역이 확장되었음을 시사하였 다. Lax Vox 음성치료는 높은 구강압과 성도의 진동으로 입 뒤쪽 압력과 성대임피던스가 증가되는데, 성대의 임피던스가 높아질수 록 갑상피열근의 움직임이 증가되며 증가된 갑상피열근의 움직임 은 성대를 유연하게 만든다(Laukkanen et al., 2008; Titze, 1993).

또한, Lax Vox 음성치료 후 음성 강도가 유의미하게 증가하였는 데 이러한 결과는 LSVT 후 파킨슨병 환자들의 음성 강도가 증가하 였다는 선행연구의 결과들과 비슷하게 나타났으며(Dromey et al., 1995; El Sharkawi et al., 2002; Martel Sauvageau, Roy, Langlois, \& Macoir, 2015; Ramig, Sapir, Fox, \& Countryman, 2001; Sapir et al., 2002; Searl et al., 2011; Spielman et al., 2011), Lax Vox가 LSVT와 마찬가지로 파킨슨병 환자의 음성 강도를 증가시키는 데 효과가 있 음을 시사하였다. LSVT에서는 좋은 음질을 가진 큰 음성 강도를 목표로 하여 치료과정 중 환자들이 종종 과다기능(hyperfunction) 을 나타내기도 한다. 이 때문에 환자가 쥐어짜거나 좋지 않은 음질 로 큰 강도를 내는 경우 임상가가 소리 훈련을 잠시 멈추게 하고 다 시 좋은 음질로 큰 강도로 소리내도록 유도하지만, Lax Vox는 이완 
된 상태에서 물에서 거품을 내면서 소리를 내기 때문에 구강압과 입 뒤쪽의 압력을 증가시켜 후두를 하강하게 함으로써 성대 내전 을 돕고 반폐쇄에 의해 성도의 관성을 증가시켜 성대진동을 촉진시 켜 준다. 본 연구의 모든 대상자들이 청지각적으로 치료후 음성 강 도가 두드러지게 증가하였으며, 실제 대상자 3 의 경우 치료 전후 후 두의 위치가수직적으로 $3 \mathrm{~cm}$ 하강하였으며, 젖은 목소리(wet voice) 가 사라지고 성대접촉이 증가하고 삼킴장애가 감소하였다. 이와 더 불어, 청지각적으로도 음질이 크게 개선이 되었는데 이러한 변화 는 Lax Vox 음성치료가 성대접촉 시 손상을 최소화하면서도 접촉 은 강화시켜 불규칙하였던 파킨슨병 환자들의 성대진동을 안정화 시켰음을 의미한다. 이러한 결과는 LSVT 후 파킨슨병 환자들의 음 성이 청지각적으로 음질이 개선되었다는 선행연구의 결과들과도 일치된 결과를 보였다(Halpern et al., 2012; Ramig \& Fox, 2019; Sapir et al., 2002; Sapir, Spielman, Ramig, Story, \& Fox, 2007; Whitehill, Kwan, Lee, \& Chow, 2011). 실제 대상자 1, 6, 9는 치료후 음성 진전이 없어졌으며, 나머지 대상자들도 불안정한 음성이 개선됨을 나타내었다.

Lax Vox 음성치료 후 통계적으로는 유의하지 않았으나, 성문폐 쇄율이 증가하였다. 또한, 본 연구결과 치료후 음성장애지수가 감 소하여 Lax Vox 음성치료 후 파킨슨병 환자들의 음성만족도가 향 상되었다. 이는 LSVT 후 파킨슨병 환자들의 VHI 총점이 감소하였 다는 선행연구의 결과들과 일치하였으며(Halpern et al., 2012; Sackley et al., 2018; Saffarian, Shavaki, Shahidi, Hadavi, \& Jafari, 2019; Searl et al., 2011; Spielman et al., 2011; Wight \& Miller, 2015), Lax Vox 음성치료가 파킨슨병 환자에게 높은 만족도를 제공하는 음성 치료방법으로 나타났다.

현재까지는 LSVT가 파킨슨병 환자의 말음성개선을 위한 근거 기반중재(evidence-based practice)로 알려져 있으나, 위의 결과를 미루어 보았을 때, Lax Vox 음성치료가 파킨슨병 환자의 호흡 및 발 성 능력에 긍정적인 영향을 미쳐 음도 및 강도, 음질이 개선되었으 며 더욱 효율적으로 음성을 산출할 수 있었음을 알수 있다. 대상자 7은 Lax Vox 음성치료 후 노래를 부를 때 고음이 잘 나오고 음도 변 화가 이전보다 좋아졌다고 보고하였으며, 대상자 3 은 흡인의 횟수 가 감소하면서 삼킴장애가 개선되고 호흡 능력이 향상되어 하모니 카 연주를 배우기 시작하였다고 보고하였다. 또한, 음성 강도가 증 가함으로 인하여 청지각적으로 말명료도가 뚜렷이 개선되었다. 본 연구에서는 말명료도의 객관적 수치는 제시하지 않았으나, 실제로 대상자 3 은 음성 강도가 너무 작아서 이름을 불러도 잘 알아들을 수 없었으나, 치료후 아파트 거실에서 방 안에 있는 아이들의 이름 을 부르고 아이들이 들을 수 있는 정도의 소리 크기로 일반화되었
다고보고하였다.

LSVT와 마찬가지로 본 연구에서는 Lax Vox 음성치료 모두 총체 적인 기법으로 파킨슨병 환자의 음성 강도를 향상시켰다. 그러나 방법적인 측면에서 LSVT는 큰 소리로 / / / 발성 시 최대한 성대의 강한 접촉과 과도한 성대의 손상을 파하기 위해 '하'로 큰 소리를 내도록 유도하지만, 종종 환자들이 노력성 발성으로 성문하압이 증 가하게 되고 음성피로를 초래할 수 있다. 또한, 임상적 경험에 의하 면, H\&Y stage가 3 이상인 환자들은 큰 강도로 소리내기 위해 입을 크게 벌리고 소리를 낼 때 턱의 강직성으로 인하여 발성 후 턱이 잘 닫히지 않는 경우도 있었다. 이에 반해 Lax Vox 음성치료는 최소한 의 성대 손상과 적은 노력으로 음성을 생성할 수 있는 효율적인 치 료방법으로서 이러한 음성효율의 증가는 음성피로를 감소시키는 것으로 보인다. 또한, 갑상피열근의 움직임이 활성화되어 성대 운동 을 촉진시켜 강직된 성대근육을 유연하게 할 수 있다. 따라서, LSVT 는 비교적 낮은 성문하압을 보이는 즉, 과소기능적 발성장애로 인 한 이차적인 보상적 발성이 형성되기 전인 환자에게 유용할 것이라 판단되며, Lax Vox 음성치료는 과다 및 과소기능적 음성장애 모두 에게 적용할 수 있기에 보상적인 발성이 형성되었더라도 유용하게 사용할 수 있으며, 중증도에 상관없이 모든 파킨슨병 환자에게 실 시할 수 있을 것이라 사료된다. 위의 결과를 미루어 보았을 때, Lax Vox 음성치료는 LSVT뿐만 아니라 파킨슨병 환자의 음성개선에 효과적인 치료방법으로 사용될 수 있으며, 파킨슨병 음성치료의 새로운 접근방식을 제시하고 더불어 근거기반중재로 사용될 수 있 는 근거를 제공할 것이라 사료된다. 그러나 본 연구에서는 적은 대 상자 수와 통제군이 없이 치료 전후만을 비교한 제한점이 있다. 추 후 연구에서는 좀더 다수의 파킨슨병 환자들을 대상으로 LSVT와 Lax Vox 음성치료를 비교하여 치료 효과를 살펴보는 것이 필요할 것이다.

\section{REFERENCES}

Alharbi, G. G., Cannito, M. P., Buder, E. H., \& Awan, S. N. (2019). Spectral/ cepstral analyses of phonation in Parkinson's disease before and after voice treatment: a preliminary study. Folia Phoniatrica et Logopaedica, 1-11. https://doi.org/10.1159/000495837

Arias, P., \& Cudeiro, J. (2008). Effects of rhythmic sensory stimulation (auditory, visual) on gait in Parkinson's disease patients. Experimental Brain Research, 186(4), 589-601.

Aronson, A. E. (1990). Clinical voice disorders: an interdisciplinary approach, 3rd ed. New York, NY: Thieme. 
Baker, K. K., Ramig, L. O., Luschei, E. S., \& Smith, M. E. (1998). Thyroarytenoid muscle activity associated with hypophonia in Parkinson disease and aging. Neurology, 51(6), 1592-1598.

Berry, D. A., Verdolini, K., Montequin, D. W., Hess, M. M., Chan, R. W., \& Titze, I. R. (2001). A quantitative output-cost ratio in voice production. Journal of Speech, Language, and Hearing Research, 44(1), 29-37.

Brown, R. G., \& Marsden, C. D. (1988). Internal versus external cues and the control of attention in Parkinson's disease. Brain, 111(2), 323-345.

Chae, H. R., Kim, J. S., Lee, D. W., \& Choi, S. H. (2019). Effects of semi-occluded vocal tract exercise in patients with functional aphonia. Journal of Korean Society of Laryngology, Phoniatrics and Logopedics, 30(1), 48-52.

Choi, S. H. (2011). The effect of Lee Silverman Voice Treatment (LSVT) on Parkinsonian phonation: nonlinear dynamic, perturbation, and perceptual analysis. Korean Journal of Communication Disorders, 16(3), 335-345.

Choi, S. H. (2012). Effects of deep brain stimulation (DBS) on speech and voice in Parkinson's disease: acoustic measures of vowels from sustained phonation and running speech using perturbation and nonlinear dynamic analysis. Korean Journal of Communication Disorders, 17(1), 143-155.

Choi, S. H. (2017). Semi-occluded vocal tract exercise accent method, straw phonation, Lax Vox. Journal of the Korean Association for Voice of Performing Arts, 4(4), 11-19.

Choi, S. H. (2018). Development of Korean standardized sentences on voice quality evaluation for dysphonia. Audiology and Speech Research, 14(2), 128-142.

Chu, I. S. (1998). The effect of revised LSVT program on voice and speech intelligibility in patients with idiopathic Parkinson disease (Master's thesis). Daegu University, Gyeongsan, Korea.

Darley, F. L., Aronson, A. E., \& Brown, J. R. (1969). Clusters of deviant speech dimensions in the dysarthrias. Journal of Speech and Hearing Research, 12(3), 462-496.

Dromey, C., Ramig, L. O., \& Johnson, A. B. (1995). Phonatory and articulatory changes associated with increased vocal intensity in Parkinson disease: a case study. Journal of Speech, Language, and Hearing Research, 38(4), 751-764.

El Sharkawi, A., Ramig, L., Logemann, J. A., Pauloski, B. R., Rademaker, A. W., Smith, C. H., ... \& Werner, C. (2002). Swallowing and voice effects of Lee Silverman Voice Treatment (LSVT): a pilot study. Journal of Neurology, Neurosurgery \& Psychiatry, 72(1), 31-36.

Fadel, C. B. X., Dassie-Leite, A. P., Santos, R. S., Santos Jr., C. G. D., Dias, C. A. S., \& Sartori, D. J. (2016). Immediate effects of the semi-occluded vocal tract exercise with LaxVox tube in singers. CoDAS, 28(5), 618-624.

Fox, C. M., Morrison, C. E., Ramig, L. O., \& Sapir, S. (2002). Current perspectives on the Lee Silverman Voice Treatment (LSVT) for individuals with idiopathic Parkinson disease. American Journal of Speech-Language Pathology, 11(2), 111-123.

Gath, I., \& Yair, E. (1988). Analysis of vocal tract parameters in Parkinsonian speech. The Journal of the Acoustical Society of America, 84(5), 1628-1634.

Gelb, D. J., Oliver, E., \& Gilman, S. (1999). Diagnostic criteria for Parkinson disease. Archives of Neurology, 56(1), 33-39.

Guzmán, M., Castro, C., Madrid, S., Olavarria, C., Leiva, M., Muñoz, D., ... \& Laukkanen, A. M. (2016). Air pressure and contact quotient measures during different semioccluded postures in subjects with different voice conditions. Journal of Voice, 30(6), 759.e1-759.e10.

Guzman, M., Rubin, A., Muñoz, D., \& Jackson-Menaldi, C. (2013). Changes in glottal contact quotient during resonance tube phonation and phonation with vibrato. Journal of Voice, 27(3), 305-311.

Halpern, A. E., Ramig, L. O., Matos, C. E., Petska-Cable, J. A., Spielman, J. L., Pogoda, J. M., ... \& McFarland, D. H. (2012). Innovative technology for the assisted delivery of intensive voice treatment (LSVT LOUD) for Parkinson disease. American Journal of Speech-Language Pathology, 21(4), 354-367.

Hillen, M. E., \& Sage, J. I. (1996). Nonmotor fluctuations in patients with Parkinson's disease. Neurology, 47(5), 1180-1183.

Jankovic, J. (2008). Parkinson's disease: clinical features and diagnosis. Journal of Neurology, Neurosurgery \& Psychiatry, 79(4), 368-376.

Jeon, C. Y. (2017). Comparison of the Lee Silverman Voice Treatment (LSVT LOUD) effects for patients with Parkinson's disease versus Parkinson-plus syndrome (Master's thesis). Daegu Catholic University, Gyeongsan, Korea.

Jiang, J., O’Mara, T., Chen, H. J., Stern, J. I., Vlagos, D., \& Hanson, D. (1999). Aerodynamic measurements of patients with Parkinson's disease. Journal of Voice, 13(4), 583-591.

Kang, Y. A. (2007). Effects of the Lee Silverman Voice Treatment (LSVT) on voice quality of patients with Parkinson's disease (Master's thesis). Chungnam National University, Daejeon, Korea.

Kent, R. D., Vorperian, H. K., Kent, J. F., \& Duffy, J. R. (2003). Voice dysfunction in dysarthria: application of the Multi-Dimensional Voice Program. Journal of Communication Disorders, 36(4), 281-306.

Kim, J. S., \& Choi, S. H. (2018). Effects of self voice care program for Korean speech-language pathologists. Proceedings of the 20th International Conference on Korean Speech-Language \& Hearing Association, 1-4.

Kim, J. S., Lee, D. W., Choi, C. H., \& Choi, S. H. (2017). Effects of laryngeal 
massage and semi-occluded vocal tract exercises for patients with hyperfunctional dysphonia. Communication Sciences \& Disorders, 22(4), 806817.

Kim, J. U., Ghang, G. Y., \& Bae, S. C. (2002). The review of Parkinson's Disease (PD) for physical therapist. The Journal of Korean Academy of Orthopedic Manual Physical Therapy, 8(2), 73-87.

Koller, W. C. (1984). Sensory symptoms in Parkinson's disease. Neurology, 34(7), 957-959.

Laukkanen, A. M., Titze, I. R., Hoffman, H., \& Finnegan, E. (2008). Effects of a semioccluded vocal tract on laryngeal muscle activity and glottal adduction in a single female subject. Folia Phoniatrica et Logopaedica, 60(6), 298311.

Lee, J. Y. (2007). Acoustic analysis of speech in patients with idiopathic Parkinson's disease (Master's thesis). Chungnam National University, Daejeon, Korea.

Lim, H. J., Choi, S. H., Kim, J. K., \& Choi, C. H. (2016). Effects of Lax Vox voice therapy in a patient with spasmodic dysphonia: a case report. Phonetics and Speech Sciences, 8(2), 57-63.

Martel Sauvageau, V., Roy, J. P., Langlois, M., \& Macoir, J. (2015). Impact of the LSVT on vowel articulation and coarticulation in Parkinson's disease. Clinical Linguistics \& Phonetics, 29(6), 424-440.

Perez, K. S., Ramig, L. O., Smith, M. E., \& Dromey, C. (1996). The Parkinson larynx: tremor and videostroboscopic findings. Journal of Voice, 10(4), 354361.

Poewe, W. (2008). Non-motor symptoms in Parkinson's disease. European Journal of Neurology, 15(S1), 14-20.

Ramig, L. (1994). Voice treatment for patients with Parkinson disease: development of an approach and preliminary efficacy data. Journal of Medical Speech-Language Pathology, 2, 191-209.

Ramig, L., \& Fox, C. (2019). Use of LSVT LOUD (Lee Silverman Voice Treatment) in the care of a patient with Parkinson disease. In J. C. Stemple \& E. R. Hapner (Eds.), Voice therapy: clinical case studies (pp. 281-291). San Diego, CA: Plural Publishing.

Ramig, L. O. (1995). Voice therapy for neurologic disease. Current Opinion in Otolaryngology \& Head and Neck Surgery, 3(3), 174-182.

Ramig, L. O., Countryman, S., Thompson, L. L., \& Horii, Y. (1995). Comparison of two forms of intensive speech treatment for Parkinson disease. Journal of Speech, Language, and Hearing Research, 38(6), 1232-1251.

Ramig, L. O., \& Dromey, C. (1996). Aerodynamic mechanisms underlying treatment-related changes in vocal intensity in patients with Parkinson disease. Journal of Speech, Language, and Hearing Research, 39(4), 798-807.

Ramig, L. O., Sapir, S., Fox, C., \& Countryman, S. (2001). Changes in vocal loudness following intensive voice treatment (LSVT) in individuals with Parkinson's disease: a comparison with untreated patients and normal agematched controls. Movement Disorders, 16(1), 79-83.

Rubow, R., \& Swift, E. (1985). A microcomputer-based wearable biofeedback device to improve transfer of treatment in Parkinsonian dysarthria. Journal of Speech and Hearing Disorders, 50(2), 178-185.

Sackley, C. M., Smith, C. H., Rick, C. E., Brady, M. C., Ives, N., Patel, S., ... \& Jowett, S. (2018). Lee Silverman Voice Treatment versus standard speech and language therapy versus control in Parkinson's disease: a pilot randomised controlled trial (PD COMM pilot). Pilot and Feasibility Studies, 4(1), 30.

Saffarian, A., Shavaki, Y. A., Shahidi, G. A., Hadavi, S., \& Jafari, Z. (2019). Lee Silverman voice treatment (LSVT) mitigates voice difficulties in mild Parkinson's disease. Medical Journal of the Islamic Republic of Iran, 33, 5.

Sapir, S., Ramig, L. O., Hoyt, P., Countryman, S., O’Brien, C., \& Hoehn, M. (2002). Speech loudness and quality 12 months after intensive voice treatment (LSVT) for Parkinson's disease: a comparison with an alternative speech treatment. Folia Phoniatrica et Logopaedica, 54(6), 296-303.

Sapir, S., Spielman, J. L., Ramig, L. O., Story, B. H., \& Fox, C. (2007). Effects of intensive voice treatment (the Lee Silverman Voice Treatment [LSVT]) on vowel articulation in dysarthric individuals with idiopathic Parkinson disease: acoustic and perceptual findings. Journal of Speech, Language, and Hearing Research, 50(4), 899-912.

Schulz, G. M., \& Grant, M. K. (2000). Effects of speech therapy and pharmacologic and surgical treatments on voice and speech in Parkinson's disease: a review of the literature. Journal of Communication Disorders, 33(1), 5988.

Searl, J., Wilson, K., Haring, K., Dietsch, A., Lyons, K., \& Pahwa, R. (2011). Feasibility of group voice therapy for individuals with Parkinson's disease. Journal of Communication Disorders, 44(6), 719-732.

Sewall, G. K., Jiang, J., \& Ford, C. N. (2006). Clinical evaluation of Parkinson's-related dysphonia. The Laryngoscope, 116(10), 1740-1744.

Sihvo, M., \& Denizoglu, I. (2013). Lax vox voice therapy technique. http:// www.laxvox.com/.

Simberg, S., \& Laine, A. (2007). The resonance tube method in voice therapy: description and practical implementations. Logopedics Phoniatrics Vocology, 32(4), 165-170.

Simberg, S., Rae, J., Kallvik, E., Salo, B., \& Martikainen, K. (2012). Effects of 
speech therapy on voice and speech in Parkinson's after a 15-day rehabilitation course: a pilot study. International Journal of Therapy and Rehabilitation, 19(5), 273-285.

Snider, S. R., Fahn, S., Isgreen, W. P., \& Cote, L. J. (1976). Primary sensory symptoms in parkinsonism. Neurology, 26(5), 423-423.

Solomon, N. P., \& Charron, S. (1998). Speech breathing in able-bodied children and children with cerebral palsy: a review of the literature and implications for clinical intervention. American Journal of Speech-Language Pathology, 7(2), 61-78.

Sovijärvi, A. (1969). Nya metoder vid behandlingen av röstrubbningar. Nordisk Tidskrift for Tale og Stemme, 3, 121-131.

Spielman, J., Mahler, L., Halpern, A., Gilley, P., Klepitskaya, O., \& Ramig, L. (2011). Intensive voice treatment (LSVT LOUD) for Parkinson's disease following deep brain stimulation of the subthalamic nucleus. Journal of Communication Disorders, 44(6), 688-700.

Titze, I. R. (1993). Current topics in voice production mechanisms. Acta Otolaryngologica, 113(3), 421-427.

Titze, I. R. (2002a). How to use the flow resistant straws. Journal of Singing,
58(5), 429-430.

Titze, I. R. (2002b). Raising lung pressure and pitch in vocal warm-ups: the use of flow-resistant straws. Journal of Singing, 58(4), 329-338.

Titze, I. R. (2006). Voice training and therapy with a semi-occluded vocal tract: rationale and scientific underpinnings. Journal of Speech, Language, and Hearing Research, 49(2), 448-459.

Tyrmi, J., Radolf, V., Horáček, J., \& Laukkanen, A. M. (2017). Resonance tube or lax vox? Journal of Voice, 31(4), 430-437.

Whitehill, T. L., Kwan, L., Lee, F. P. H., \& Chow, M. M. N. (2011). Effect of LSVT on lexical tone in speakers with Parkinson's disease. Parkinson's Disease, $2011,897494$.

Wight, S., \& Miller, N. (2015). Lee Silverman Voice Treatment for people with Parkinson's: audit of outcomes in a routine clinic. International Journal of Language \& Communication Disorders, 50(2), 215-225.

Yun, Y. S., Kim, H., Son, Y. I., \& Choi, H. S. (2008). Validation of the Korean Voice Handicap Index (K-VHI) and the clinical usefulness of Korean VHI10. Korean Journal of Communication \& Disorders, 13(2), 216-241. 


\section{국문초록}

\section{Lax Vox 음성치료가 파킨슨병 환자의 호흡 및 발성에 미치는 효과}

채혜림 ${ }^{1} \cdot$ 최성희 ${ }^{1,2} \cdot$ 최철희 ${ }^{1,2} \cdot$ 이경재 ${ }^{1,2}$

${ }^{1}$ 대구가톨릭대학교 일반대학원, ${ }^{2}$ 대구가톨릭대학교 언어청각치료학과

배경 및 목적: 파킨슨병은 운동기능에 영향을 미치는 중추신경계의 퇴행성 질환으로 자신의 음성을 자가 모니터링을 하지 못하여 음 성의 강도와 음도 조절에 어려움을 보이는 감각장애이다. 반폐쇄성도훈련 중 Lax Vox는 튜브를 물에 넣어 발성하는 것으로 호흡, 공명, 발성의 상호작용에 초점을 맞추어 bio-feedback을 제공하는 총체적인 기법이다. 본 연구는 Lax Vox 음성치료가 파킨슨병 환자의 호흡 및 발성에 미치는 영향을 알아보고자 한다. 방법: 파킨슨병 환자 10 명(남자 4 명, 여자 6 명)을 대상으로 Lax Vox 음성치료를 주 1회 간격 으로 6 주간 총 6 회 실시하였다. 치료효과를 살펴보기 위해 음성치료 전후 공기역학적, 음향학적, 청지각적 평가, 전기성문파형 검사 및 한국어판 음성장애지수-10을 실시하였다. 결과: 음성치료 후 공기역학적, 음향학적 및 청지각적 평가 측정치와 음성장애지수가 유의하 게 개선되었다. 특히, 폐활량, 음성 강도, 최대발성지속시간이 증가하였으며, 성문하압이 유의미하게 감소하였다. CPP와 음성범위프로 파일, 발화 시 평균 강도가 유의하게 증가하였으며, $\mathrm{sPPQ}, \mathrm{vF}_{0}$, shimmer, $\mathrm{APQ}, \mathrm{sAPQ}, \mathrm{vAm}$ 가 감소하고, 한국어판 음성장애지수- 10 의 총점이 낮아졌다. 논의 및 결론: Lax Vox 음성치료는 파킨슨병 환자의 호흡 및 발성 능력에 긍정적인 효과가 있음을 확인하였으며, LSVT와 더불어 Lax Vox 음성치료는 파킨슨병 환자의 효과적인 치료법이 될 수 있음을 시사하였다.

핵심어: 파킨슨병, 감각운동장애, Lax Vox, 음성치료, 반폐쇄성도훈련

본 논문은 제1저자의 석사학위논문의 일부를 발췌한 것임.

\section{참고문헌}

강영애(2007). LSVT에 의한 파킨슨병 환자의 음성장애치료에 관한 연구. 충남대학교 대학원 석사학위논문.

김지성, 이동욱, 최철희, 최성희(2017). 후두마사지와 반폐쇄성도훈련이 과기능적 음성장애 환자의 음성개선에 미치는 효과. Communication Sciences \& Disorders, 22(4), 806-817.

김지성, 최성희(2018). 한국 언어재활사의 음성건강을 위한 자가음성관리프로그램(Self voice care program)의 효과. 제 20 회 한국언어치료학회 학술 대회, 1-4.

김진웅, 강군용, 배수찬(2002). 파킨슨 질환에 대한 문헌적 고찰. 대한정형도수물리치료학회지, 8(2), 73-87.

윤영선, 김향희, 손영익, 최홍식(2008). 한국어판 음성장애지수(Voice Handicap Index, VHI)의 타당도 및 VHI-10의 임상적 유용성. 언어청각장애연

구, 13(2), 216-241.

이준영(2007). 파킨슨병 환자 언어의 음성학적 분석. 충남대학교 대학원 석사학위논문.

임혜진, 최성희, 김정규, 최철희(2016). 연축성 발성장애 환자의 Lax Vox 음성치료 효과. 말소리와 음성과학, 8(2), 57-63.

전채연(2017). 파킨슨병 환자와 파킨슨-플러스 증후군 환자의 리실버만 음성치료 효과 비교. 대구가톨릭대학교 대학원 석사학위논문.

채혜림, 김지성, 이동욱, 최성희(2019). 반폐쇄성도훈련이 기능적 실성증환자의 음성개선에 미치는 효과. 대한후두음성언어의학회지, 30(1), 48-52. 최성희(2011). 파킨슨씨병 음성에 대한 리실버만 음성치료의 효과: 비선형의 역동적, 섭동적, 청지각적 분석. 언어청각장애연구, 16(3), 335-345.

최성희(2012). 파킨슨씨병 환자의 뇌심부자극술에 대한 말음성 효과: 섭동적 분석과 비선형 역동적 분석을 이용한 연장 발성과 연속 발화 모음의 음 향학적 분석. 언어청각장애연구, 17(1), 143-155.

최성희(2017). 공연예술가를 위한 반폐쇄성도훈련: 악센트기법, 빨대 발성, Lax Vox. 한국공연예술발성연구회지, 4, 11-19.

최성희(2018). 음성장애 환자의 음질 평가를 위한 표준문장 개발. Audiology and Speech Research, 14(2), 128-142.

추인숙(1998). LSVT 수정프로그램의 적용이 특발성 파킨슨병의 환자들의 음성 및 어음명료도에 미치는 효과. 대구대학교 대학원 석사학위논문. 


\section{ORCID}

채혜림(https://orcid.org/0000-0002-9088-5425); 최성희(https://orcid.org/0000-0003-2365-6187);

최철희(https://orcid.org/0000-0003-1844-3072); 이경재(https://orcid.org/0000-0002-6811-1212) 